\title{
Medicinal Plants Used for the Treatment of Erectile Dysfunction in Ethiopia: A Systematic Review
}

\author{
Demoze Asmerom $\mathbb{D}^{1},{ }^{1}$ Tesfay Haile Kalay $\mathbb{D}^{2}{ }^{2}$ Tsgabu Yohannes Araya ${ }^{(D)}{ }^{1}$ \\ Desilu Mahari Desta $\mathbb{D}^{\mathrm{D}}{ }^{3}$ Dawit Zewdu Wondafrash $\mathbb{D}^{\mathrm{D}}{ }^{4}$ \\ and Gebrehiwot Gebremedhin Tafere $\left.{ }^{4}\right)^{4}$ \\ ${ }^{1}$ Department of Medicinal Chemistry, School of Pharmacy, College of Health Sciences, Mekelle University, P.O. Box 1871, \\ Mekelle, Ethiopia \\ ${ }^{2}$ Department of Pharmacognosy, School of Pharmacy, College of Health Sciences, Mekelle University, P.O. Box 1871, Mekelle, Ethiopia \\ ${ }^{3}$ Clinical Pharmacy Unit and Research Team, School of Pharmacy, College of Health Sciences, Mekelle University, P.O. Box 1871, \\ Mekelle, Ethiopia \\ ${ }^{4}$ Department of Pharmacology and Toxicology, School of Pharmacy, College of Health Sciences, Mekelle University, P.O. Box 1871, \\ Mekelle, Ethiopia
}

Correspondence should be addressed to Demoze Asmerom; demoze.asmerom@mu.edu.et

Received 15 October 2020; Revised 13 May 2021; Accepted 27 May 2021; Published 8 June 2021

Academic Editor: Atef M. Al Attar

Copyright ( $) 2021$ Demoze Asmerom et al. This is an open access article distributed under the Creative Commons Attribution License, which permits unrestricted use, distribution, and reproduction in any medium, provided the original work is properly cited.

\begin{abstract}
Background. Erectile dysfunction has remained as one of the major global health issues. Since the discovery of phosphodiesterase type 5 inhibitors, a significant portion of the patients has solved the issue of erectile dysfunction. However, the wide distribution of phosphodiesterase type 5 enzymes at various sites of the body led phosphodiesterase type 5 inhibitors to cause various unnecessary outcomes. Hence, it is vital to look for and find optional agents that could solve these limitations. The people of Ethiopia depend heavily on medicinal plants to ease their ailments, including erectile dysfunction. Aim of the study. The current study was carried out to systematically review the traditional medicinal plants used for the management of erectile dysfunction in Ethiopia. Method. A systematic and manual search was conducted to retrieve relevant articles published from 2000 to August 2020. Electronic databases of PubMed (Medline), Google Scholar, and grey literature were employed to access the studies. Accordingly, fifty-four published articles and thesis papers were finally included in this study. Result. Seventy plant species have been reported for the management of erectile dysfunction in Ethiopia. The commonly recorded family was Fabaceae, followed by Asteraceae, Malvaceae, Convolvulaceae, and Solanaceae. The plant species that represented the highest number of citations were Asparagus africanus, succeeded by Ricinus communis and Carissa spinarum. The commonest plant part used was roots. Majority of the medicinal plants were administered orally. The growth forms of the reported species were primarily herbs followed by shrubs. Conclusion. The present review compiled medicinal plants utilized by the Ethiopian community to manage erectile dysfunction. The findings will serve as a reference for the selection of plants for further pharmacological, toxicological, and phytochemical investigations in developing new plant-based drugs used for the treatment of erectile dysfunction.
\end{abstract}

\section{Introduction}

Erectile dysfunction (ED) (also called impotence) is the inability to achieve or maintain an erection sufficient for satisfactory sexual performance [1]. It has remained one of the major global health issues which is usually attributed to age, diabetes mellitus, smoking, cardiovascular diseases, kidney disease, previous operations, psychological factors, and drugs $[2,3]$. Previously, about $52 \%$ of ED in men was seen in the age range of 40 to 70 years [3]. However, recent studies reported that $\mathrm{ED}$ is becoming highly prevalent even under the age of 40 [4]. In Africa, around $71.45 \%$ of people with diabetes developed ED [5]. In Ethiopia, about $60.4 \%$ of diabetic patients were reported with varying degrees of ED and the 
majority of the patients did not receive any medications [6]. More terribly, if this is not halted as early as possible, the number of ED cases globally is predicted to be 322 million by 2025 [7].

Erectile dysfunction can be managed nonpharmacologically via controlling plasma glucose levels and lipid profiles, avoiding smoking and alcohol drinking, psychological therapy, physical exercising, and external devices $[8,9]$. Pharmacologically, it can be treated with different drugs including phosphodiesterase type 5 inhibitors (PDE5-Is), such as sildenafil, vardenafil, and tadalafil; apomorphine; and synthetic prostaglandin E1 (alprostadil), phentolamine, and papaverine $[8,10]$. Of those, PDE5-Is are the most commonly suggested and used first-line treatment options in the world. However, the wide distribution of phosphodiesterase type 5 gene at various sites of the body led PDE5-Is to cause various adverse effects such as headache, myalgia, facial flushing, heartburn, nasal congestion, and vision-related problems. Moreover, disease conditions affecting the upstream nitric oxide pathways have been found with loss of efficacy [10]. Hence, it is vital to look for and find optional agents that could solve these limitations.

Since immemorial times, plants have been used as medicines to treat a myriad of human afflictions. This is because plants are a bank of bioactive compounds responsible for mitigating various disease conditions [11]. The people of Ethiopia depend heavily on medicinal plants to ease their ailments [12]. In Ethiopia, there are also more traditional healers than modern physicians [13]. Furthermore, traditional medicinal plants are considered as accessible, affordable, and acceptable in the community [14]. Around 6500 plant species are reported in the Ethiopian flora; of those, approximately $12 \%$ are endemic. In those Ethiopian floras, about 1000 plant species are identified as medicinal plants. However, the majority of the plant species are not yet identified [15]. This highlights that screening of the Ethiopian plants might grant various novel structures that might be unlikely to be discovered from other sources; ultimately, they may serve as lead compounds to fight various ailments including ED. Hence, documenting, compiling, and then assessing the effect of traditionally claimed plant species are worthwhile to come up with novel plant-based therapies.

\section{Aim of the Study}

The current study was carried out to systematically compile and document the traditional medicinal plants used for the management of ED or impotence in Ethiopia. The central thesis of this paper is therefore to encourage researchers to scientifically confirm the effect of medicinal plants against the global issue of ED.

\section{Methods}

This review was carried out following the recommendations stated in the Preferred Reporting Items for Systematic Reviews and Meta-Analyses (PRISMA) statement [16]. The search strategy flow chart is presented in Figure 1.
3.1. Search Strategy. A web-based systematic research literature search strategy was conducted through various electronic databases including PubMed (Medline), Google Scholar, and grey literature to access the relevant studies. The following search terms and combinations were used to collect relevant results: erectile dysfunction, impotence, traditional medicine, medicinal plants, ethnomedicine, ethnobotany, ethnopharmacology, indigenous, folk medicine, home remedy, herbal medicine, and Ethiopia.

\subsection{Study Selection}

3.2.1. Inclusion Criteria. Original published articles and thesis dissertations conducted over the period from 2000 to August 2020 were only searched. The studies written in the English language were only searched. Finally, studies with Ethiopian traditional medicinal plants exclusively utilized for the treatment of ED/impotency in humans were selected.

3.2.2. Exclusion Criteria. Articles pertaining outside Ethiopia, pharmacological studies, ethnoveterinary studies, and reviewed papers were excluded. Besides, the studies failed to mention the scientific name of the plant and the plant parts used were excluded from this study.

3.3. Data Retrieval. Studies that have possessed the required information are extracted. The required information was the family name, scientific name, local name (if available), habitat, parts used, method(s) of preparation (if available), and mode of administration. In case of missed information in some studies, especially the habitat of the plants, family name, and misspelled scientific name, information was retrieved from the Global Plants Journal of Storage (JSTOR) database [17].

3.4. Data Analysis. Microsoft Excel 2016 was employed to analyze the frequency distribution of families, plant parts, routes of administration, and habits. Besides, the distribution in regions where the medicinal plants were reported was analyzed. The results were depicted in charts and tables.

\section{Results and Discussion}

4.1. Distribution of Medicinal Plants. The regions of Ethiopia that showed the highest ethnobotanical records were Oromia (35\%) and Amhara (27\%) that constituted about two-thirds $(62 \%)$ of the total ethnobotanical records against ED (Figure 2). Several medicinal plants have been found in the Oromia region, according to most studies. This may be because, in addition to having a large number of traditional healers, those regions are also Ethiopia's most populous [18]. However, studies on the prevalence of ED in different regions of Ethiopia are limited.

4.2. Diversity of Medicinal Plants. As shown in Table 1, the current review reported 70 Ethiopian plant species that have traditionally been used to treat ED. The top recorded families were Fabaceae (6 species), Asteraceae (5 species), Malvaceae (5 species), Convolvulaceae (4 species), Solanaceae (4 species), and Euphorbiaceae (3 species) (Figure 3). Alike this study, Semenya and Potgieter [19] reported that Fabaceae 


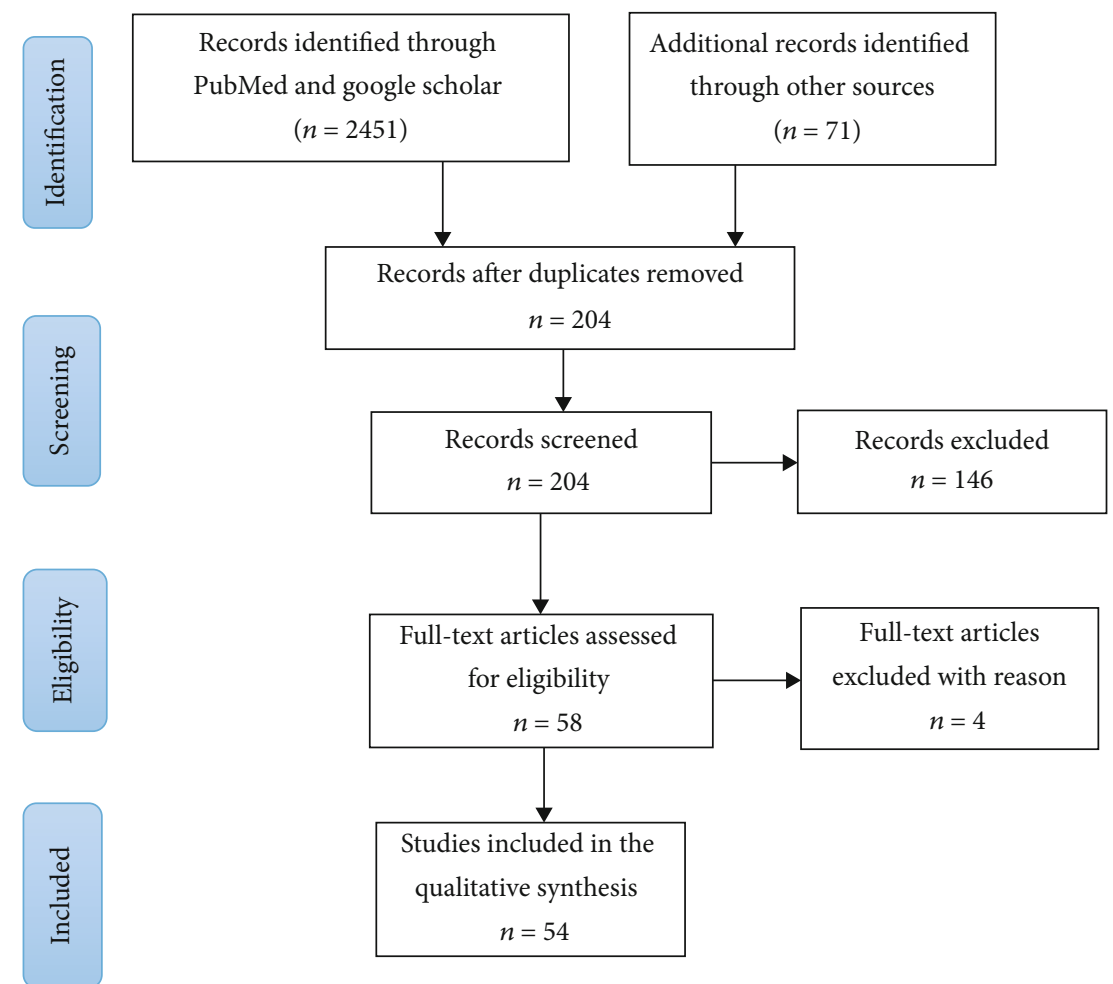

Figure 1: Study flow diagram.

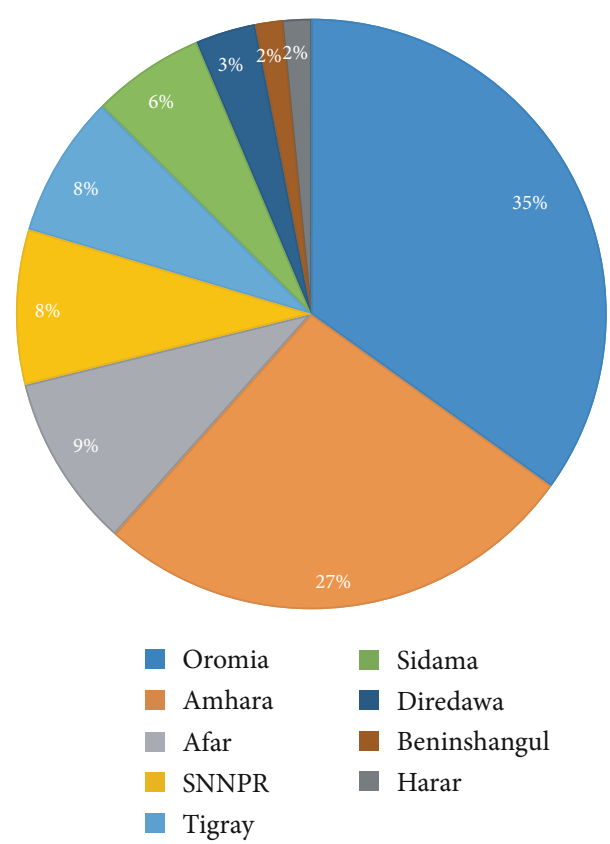

FIgURE 2: Distribution of medicinal plants across regions of Ethiopia.

and Asteraceae were among the commonly used families for ED. Ajao et al. [20] also stated that medicinal plants under Fabaceae were the top species used for the management of ED in Sub-Saharan Africa. Moreover, the root of Eriosema kraussianum N. E. Br., Fabaceae, displayed a promising effect for ED in experimental rat models [21]. According to a recent study in Ethiopia, plants in the Fabaceae family are the most commonly used traditional medicinal plants [18]. As a result, these studies highlight the screening of plant species belonging to the Fabaceae family that could be important candidates to bring lead compounds to be used for future optional agents.

4.3. Frequently Used Medicinal Plants. The plant species that represented the highest number of citations were Asparagus africanus Lam. (8 citations), Ricinus communis L. (6 citations), and Carissa spinarum L. (4 citations), as well as Ferula communis L., Aloe macrocarpa Tod., and Tragia brevipes Pax with three citations each. Congruent to the present study, the people of Nigeria also traditionally use the root of Asparagus africanus Lam. for the management of ED [75]. The usage of this plant for the treatment of ED might be due to the presence of saponins [76], because plant species with saponins as their major constituent displayed significant promotion of erection [77]. The second most cited plant species is Ricinus communis L. (also known as castor bean). Recent in vivo studies of Ricinus communis L. have confirmed that it increases serum testosterone levels and multiple majors of sexual activity, supporting the current conventional claim [78]. The third cited plant, Carissa spinarum L., alike the Ethiopian people, the people of South and Central Benin use its roots for the treatment of sexual weakness. As a result, scientific evaluation of these claimed species is needed in order to uncover important leads in the fight against ED.

Plant species like Syzygium aromaticum L., Zingiber officinale Roscoe, and Gloriosa superba L are traditionally claimed in Ethiopia; they scientifically displayed significant 


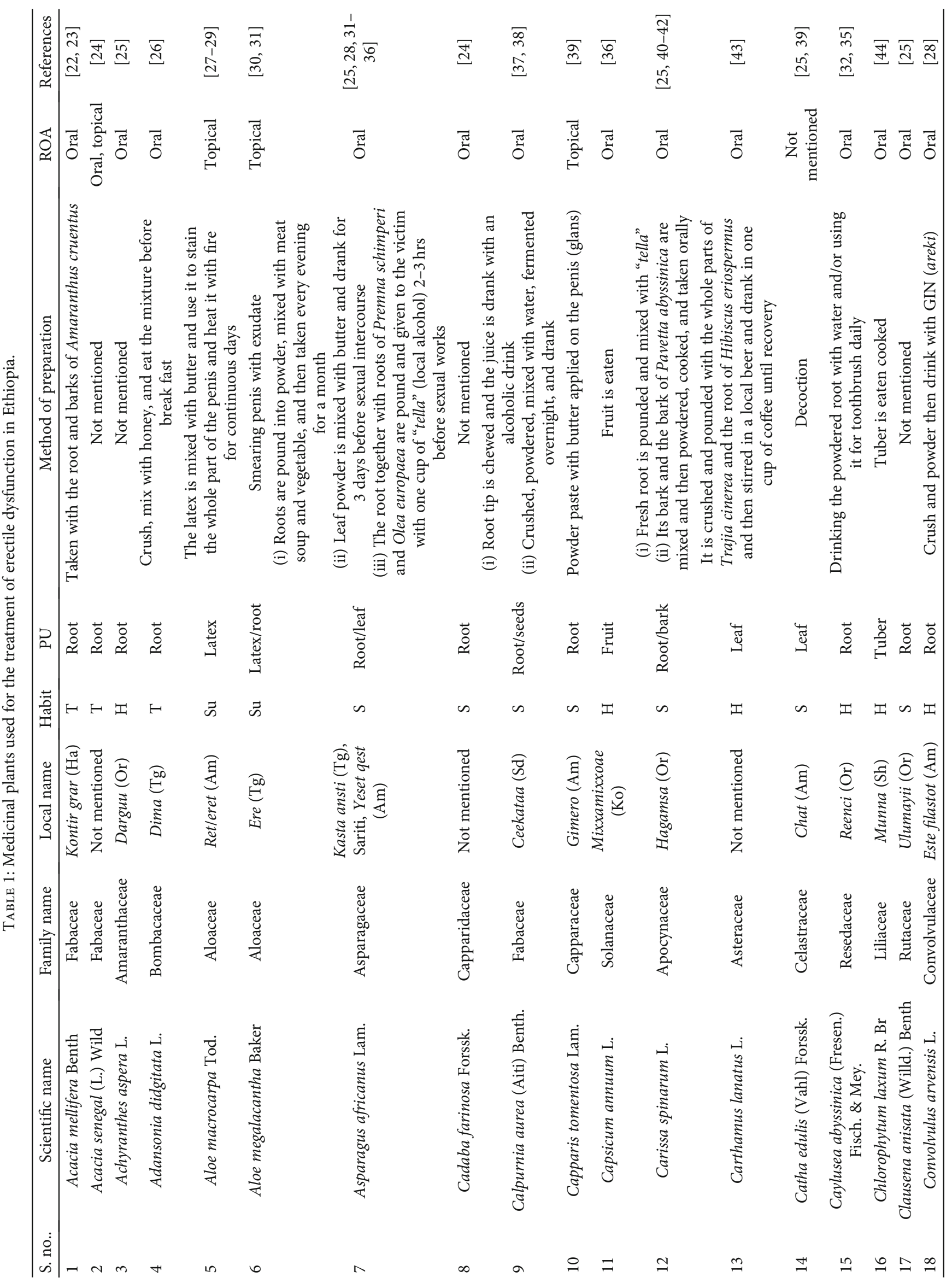




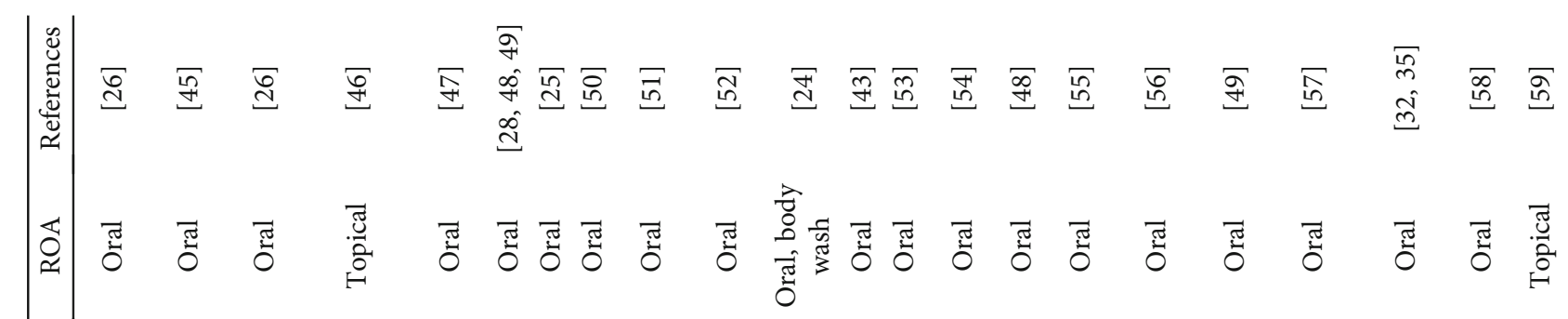

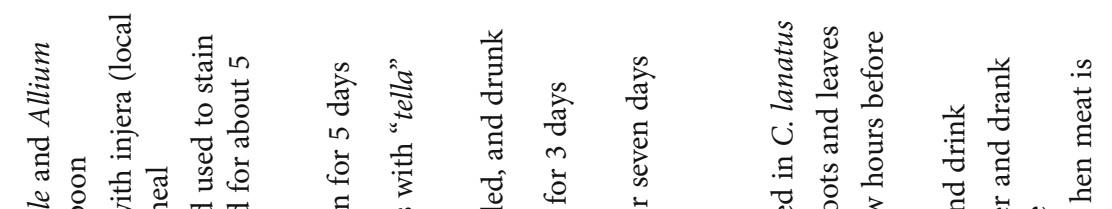

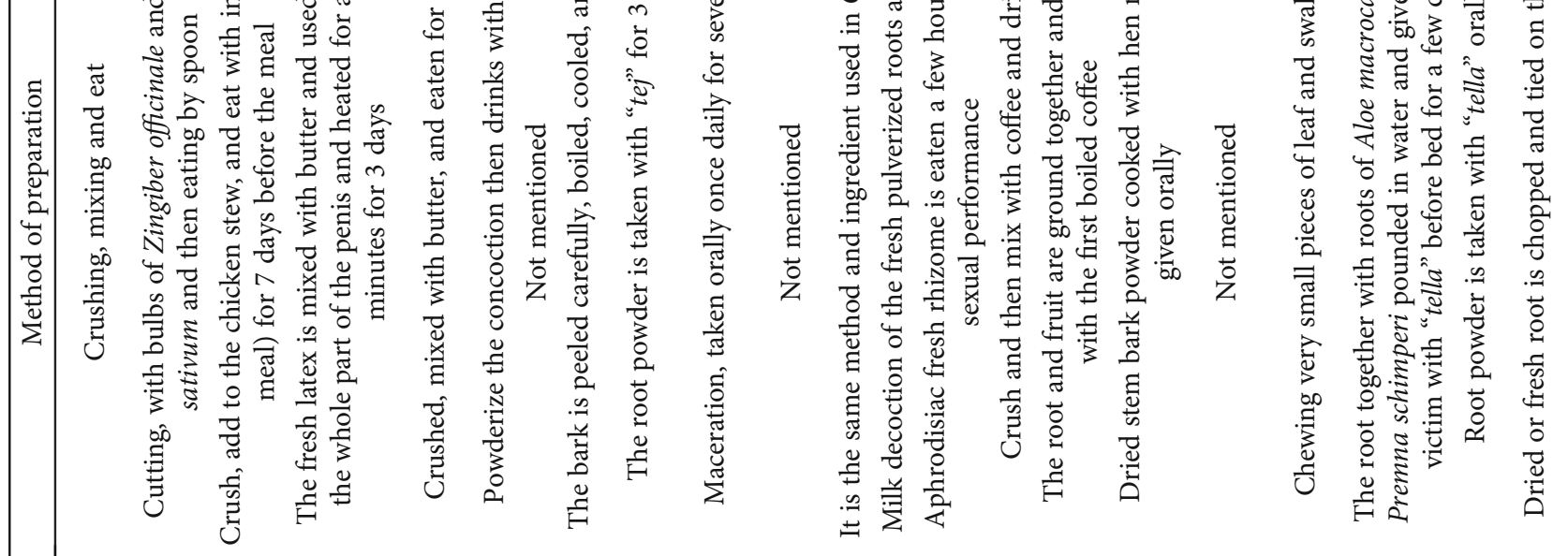

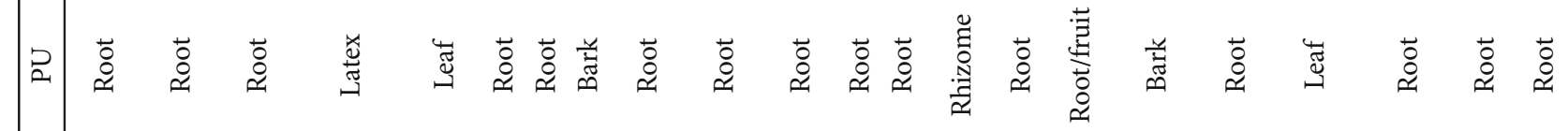

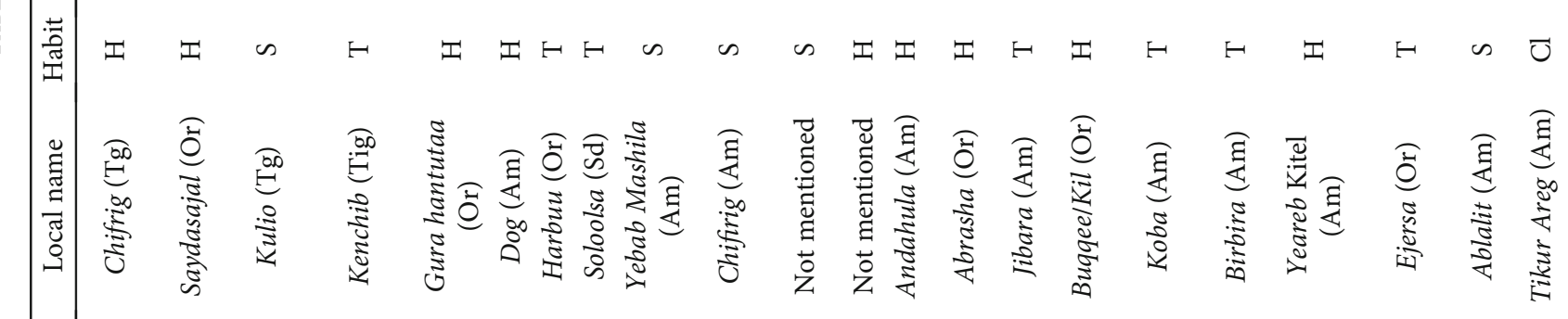

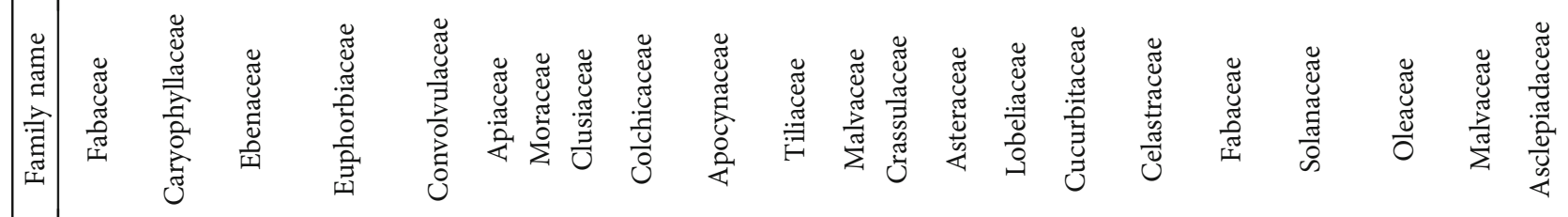

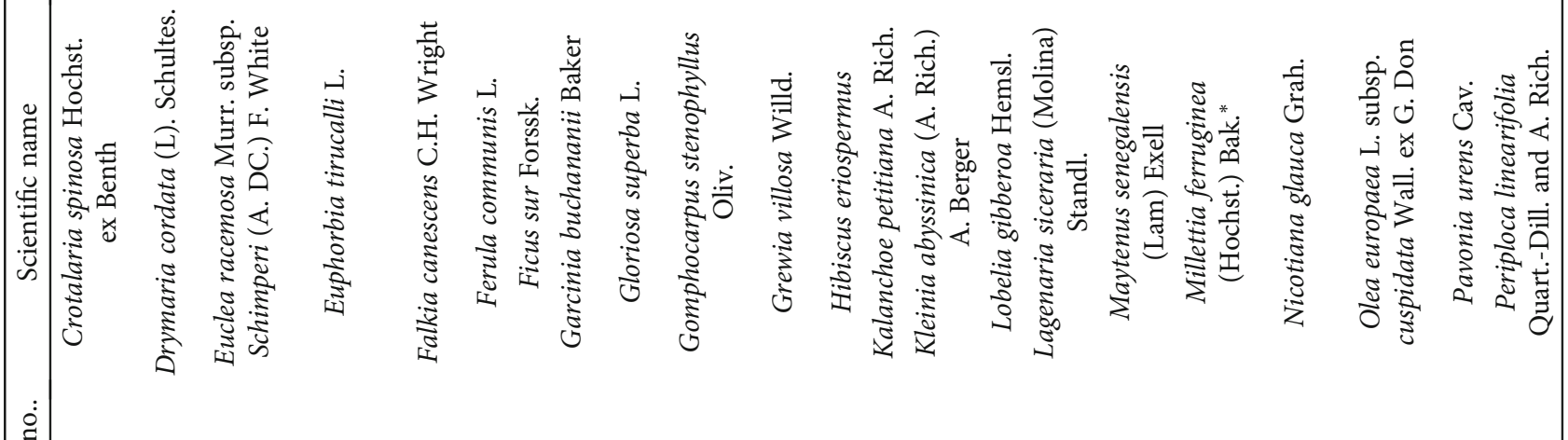

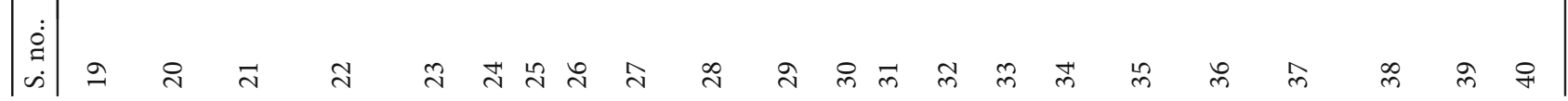




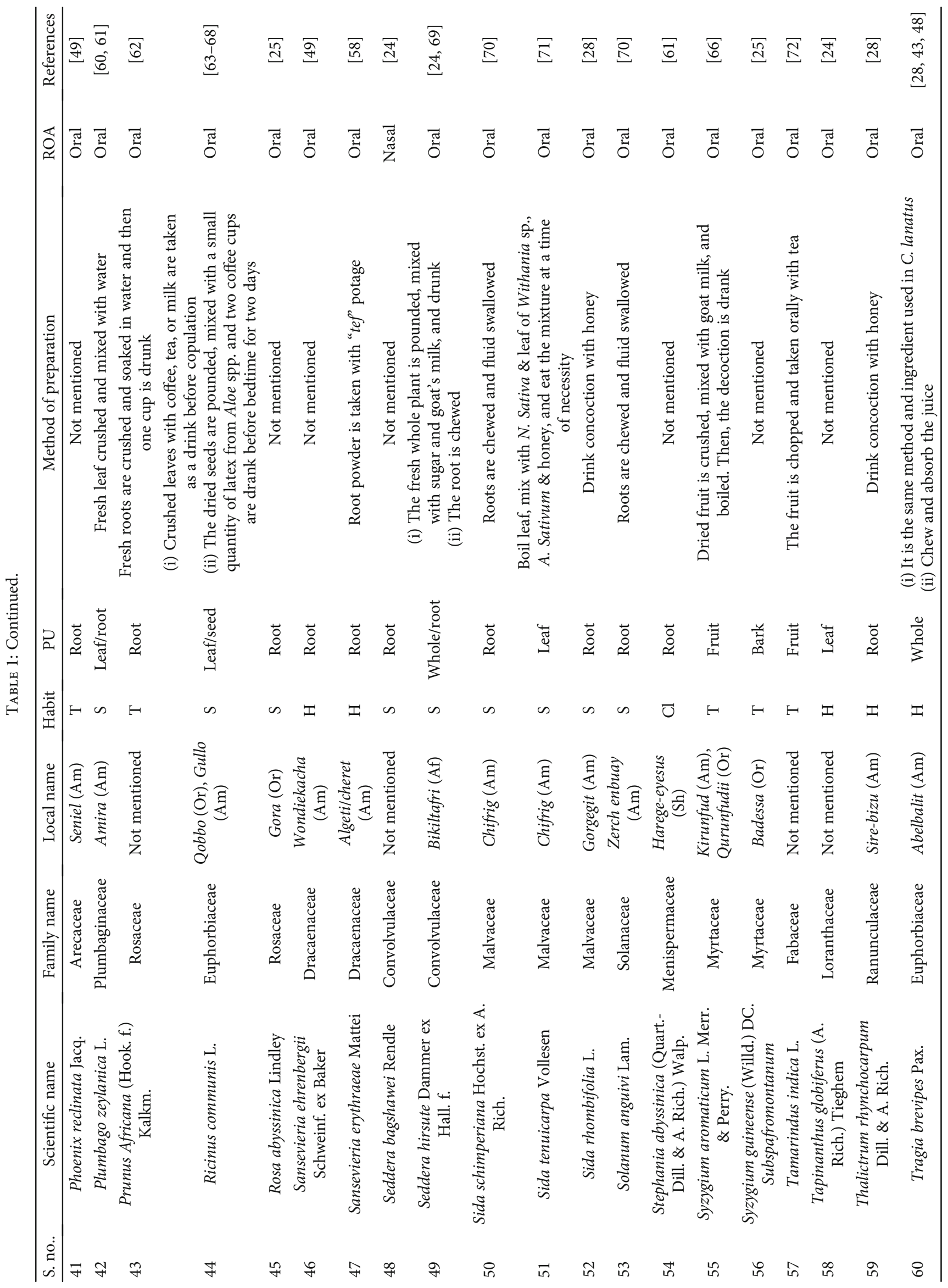




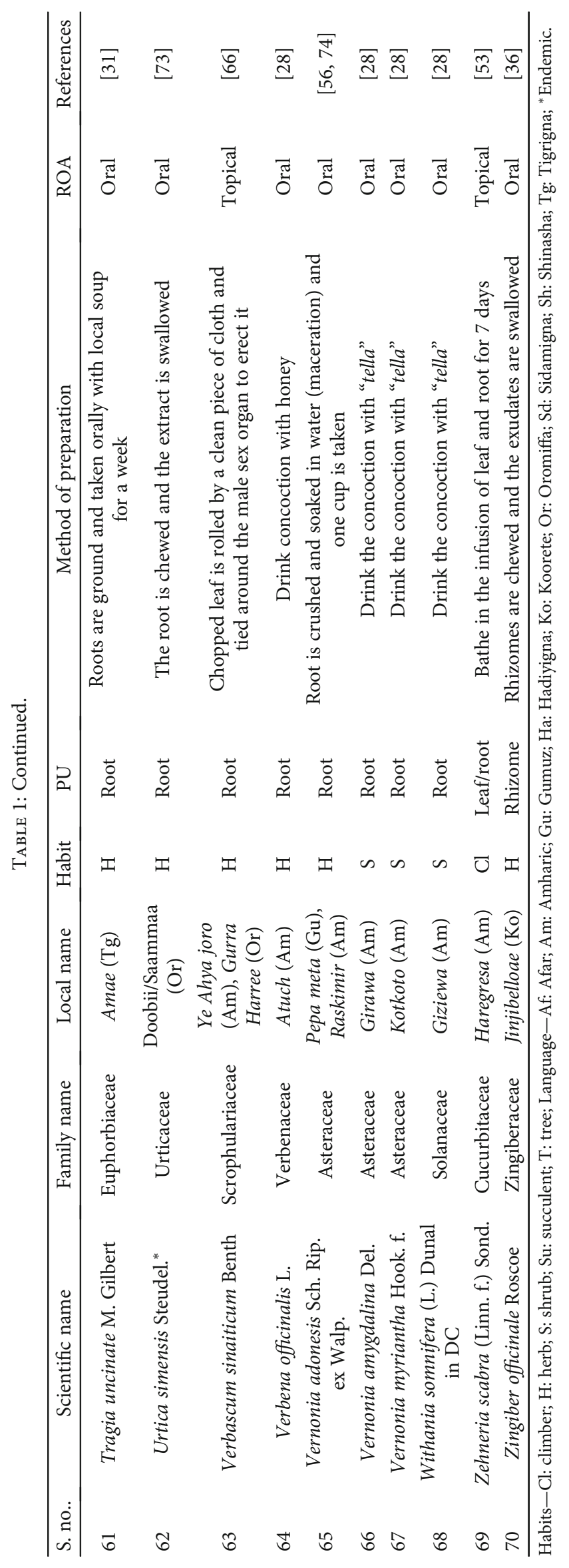




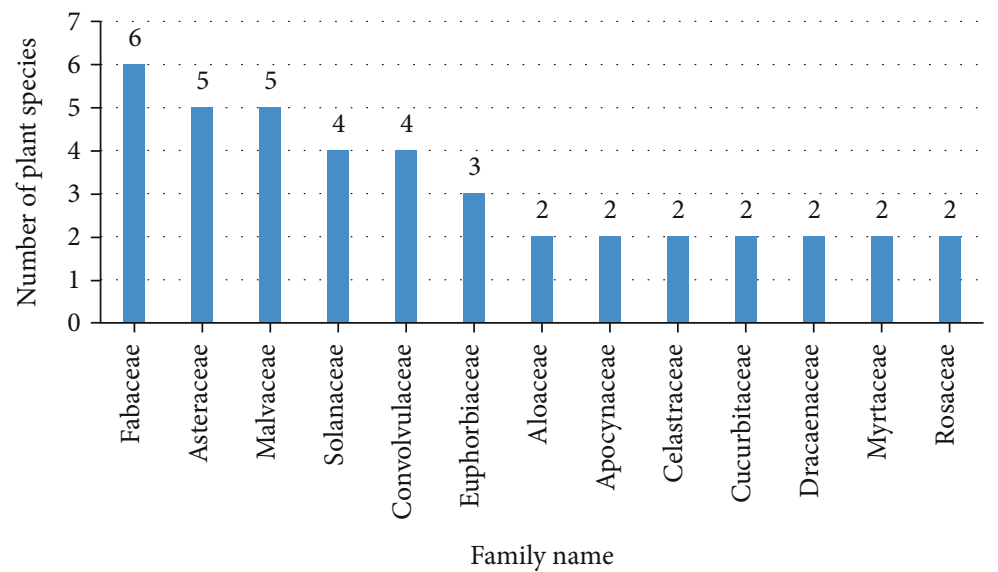

FIGURE 3: Diversity of medicinal plants used for the management of ED, for families with more than two species.

aphrodisiac effect. That is, $50 \%$ ethanolic extract of Syzygium aromaticum L., (oral; 100, 250, and $500 \mathrm{mg} / \mathrm{kg}$ to rats) improved libido and erection, intromission frequency, mounting behavior, and mating performance $[79,80]$. Hexane extract of the flower bud of Syzygium aromaticum (L.) Merr. \& Perry. (clove) (oral; $15 \mathrm{mg} / \mathrm{kg}$ to mice) raised delta (5) 3-beta and 17-beta-hydroxysteroid dehydrogenase $\left(\Delta^{5}\right.$, $3 \beta$-HSD, and $17 \beta$-HSD) and serum levels of testosterone [81]. Aqueous extract of Zingiber officinale (oral; $600 \mathrm{mg} / \mathrm{kg}$ to male Wistar rats) was tested for its possible androgenic activity and increased testis relative weight, serum testosterone, testicular cholesterol, and epididymal $\alpha$-glucosidase activity [82]. Aqueous, chloroform, and alcohol extracts of Gloriosa superba at the dose of $500 \mathrm{mg} / \mathrm{kg}$ body weight showed an aphrodisiac effect with an increase in sexual and orientation behavior. Its aphrodisiac effect could be due to the presence of steroids, saponins, and alkaloids [83]. Hence, these studies support the acclaimed use of these plant species as a treatment for sexual dysfunction in Ethiopia.

These days, in Ethiopia, the continuation of traditional plant remedies is highly threatened due to deforestation, overgrazing, environmental degradation, agricultural expansion, and the rise of the population [15]. This, in turn, jeopardizes the extinction of essential medicinal plants which may have stored indispensable compounds that are responsible for addressing the existing global health issues. Therefore, early detection of the pharmacological activities of the reported species against ED is strongly recommended.

4.4. Growth Forms of the Medicinal Plants. The growth forms of the reported species were herb (37\%), shrub (34\%), tree (22\%), climber (4\%), and succulent (3\%) (Figure 4). This study is consistent with studies conducted by Worku [12] and Yirgu et al. [18] who reported that herbs were the most dominant plant growth forms as well as used as remedies in the Ethiopian traditional medicine. The highest use of herbaceous plants as compared to other growth forms could be due to their accessibility, the higher possibility of obtaining pharmacologically active compounds, and the sociocultural beliefs and practices of the healers in treating the ailment [84].

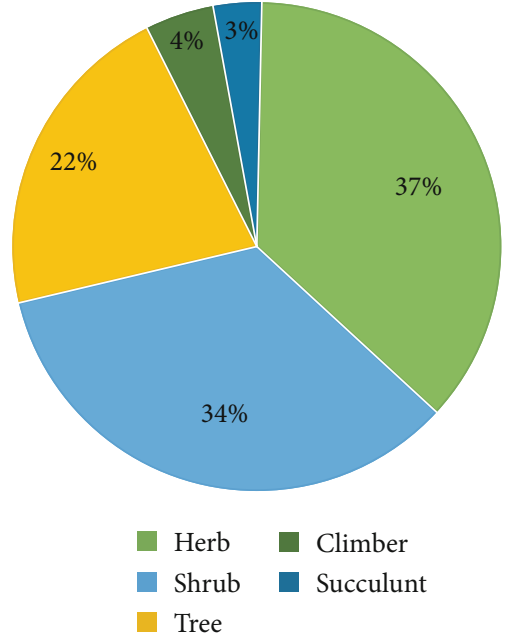

Figure 4: Growth forms of medicinal plants.

4.5. Plant Parts Used. The most common plant part used was root (41 species), followed by leaves ( 7 species), fruit ( 3 species), and bark (3 species) (Figure 5). Similarly, in another study, it was reported that the root was the predominant plant part used for the management of ED [85]. The people of South Africa, Limpopo province, also use roots as the most preferred medicinal plant part [19]. In contrast to this study, the people of Western Uganda use leaves as the commonest plant part for ED [86]. Irrespective of the dominancy, however, confirming the pharmacological activity of the claimed plant part is necessary, because most plant parts reside several bioactive principles.

4.6. Mode of Administration. The most common route of administration of the medicinal plants was oral $(86 \%)$, followed by topical (10\%), oral/topical (3\%), and nasal (1\%) (Figure 6). In agreement with this study, Semenya and Potgieter [19] mentioned the oral route as the dominant route for ED. The commonly reported cosolvents were "tella (local drink)" (8 species), butter, honey (5 species), and coffee (4 species). 


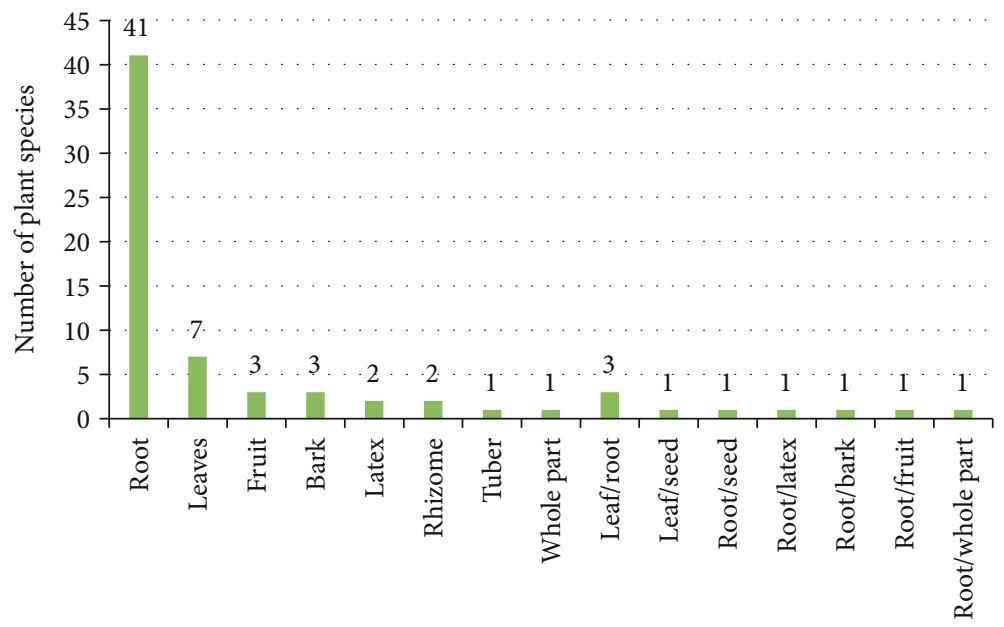

Plant parts used

Figure 5: Plant parts used for ED.

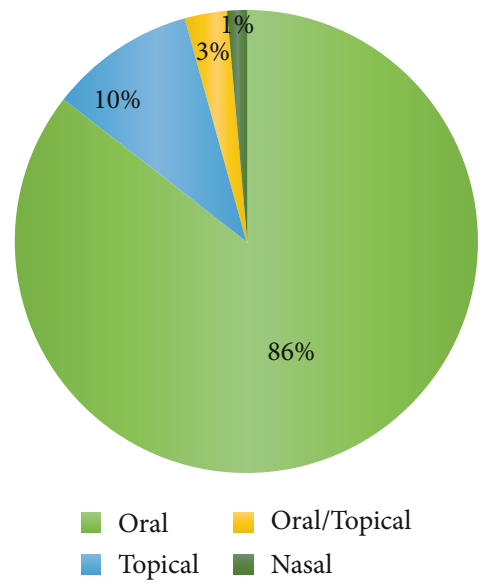

FIgURE 6: Mode of administration of the medicinal plant.

\section{Conclusion}

The present review compiles and documents for the first time seventy (70) medicinal plant species used for the management of ED in Ethiopia. Fabaceae was the dominant plant family used for the management of ED in Ethiopia. Asparagus africanus was the most repeatedly cited plant species against ED. Plant species like Syzygium aromaticum L., Zingiber officinale Roscoe, and Gloriosa superba L. are traditionally claimed in Ethiopia; they scientifically displayed significant aphrodisiac effect. This suggests the reported plant species could be a source of a new class of drugs against ED. Thus, the current findings may serve as references for the selection of plants for further pharmacological, toxicological, and phytochemical investigations in developing new plant-based drugs used for the treatment of ED.

\section{Abbreviations}

ED: $\quad$ Erectile dysfunction

PDE5-Is: Phosphodiesterase type 5 inhibitors.

\section{Data Availability}

The datasets used to support the findings of this study are available from the corresponding author upon request.

\section{Conflicts of Interest}

All authors declared that they have no conflict of interest.

\section{Authors' Contributions}

DA designed and developed the first drafted manuscript. THK and TYA screened genuinely, if there are any missed relevant articles. DZW, DMD, and GGT reviewed and edited the whole manuscript. Finally, all authors reviewed and approved the manuscript.

\section{References}

[1] F. A. Yafi, L. Jenkins, M. Albersen et al., "Erectile dysfunction," Nature Reviews. Disease Primers, vol. 2, no. 1, pp. 1-20, 2016.

[2] P. Birowo, I. A. Deswanto, and N. Rasyid, "Epidemiology of erectile dysfunction: A cross-sectional web-based survey conducted in an Indonesian national referral hospital," F1000Research, vol. 8, p. 817, 2019.

[3] D. F. Mobley, M. Khera, and B. Neil, "Recent advances in the treatment of erectile dysfunction," Postgraduate Medical Journal, 2017, [cited 2020 Sep 21]. Available from: https://pmj.bmj .com/content/93/1105/679.abstract.

[4] H. M. T. Nguyen, A. T. Gabrielson, and W. J. G. Hellstrom, "Erectile dysfunction in young men-a review of the prevalence and risk factors," Sexual Medicine Reviews., vol. 5, no. 4, pp. 508-520, 2017.

[5] W. S. Shiferaw, T. Y. Akalu, and Y. A. Aynalem, "Prevalence of erectile dysfunction in patients with diabetes mellitus and its association with body mass index and glycated hemoglobin in Africa: a systematic review and meta-analysis [Internet]," International Journal of Endocrinology Vol. 2020, Hindawi; 2020 [cited 2020 Sep 21]. p. e5148370. Available from: https://www.hindawi.com/journals/ije/2020/5148370/. 
[6] A. D. Hurisa and G. Z. Negera, "Erectile dysfunction among diabetic patients in a tertiary hospital of Southwest Ethiopia," The Open Public Health Journal [Internet], 2020, 31 [cited 2020 Sep 21];13(1). Available from: https://benthamopen .com/ABSTRACT/TOPHJ-13-240.

[7] C. Aydin and E. Senel, "Impotence literature: Scientometric analysis of erectile dysfunction articles between 1975 and 2018," Andrologia, vol. 52, no. 3, article e13520, 2020.

[8] A. F. A. Diniz, R. C. Ferreira, I. L. L. de Souza, and B. A. Silva, "Ionic Channels as Potential Therapeutic Targets for Erectile Dysfunction: A Review," Frontiers in Pharmacology, vol. 11, p. 1120, 2020.

[9] R. Wassersug and E. Wibowo, "Non-pharmacological and non-surgical strategies to promote sexual recovery for men with erectile dysfunction," Translational Andrology and Urology., vol. 6, Suppl 5, pp. S776-S794, 2017.

[10] S. Kim, M. C. Cho, S. Y. Cho, H. Chung, and M. R. Rajasekaran, "Novel Emerging therapies for erectile dysfunction," The World Journal of Men's Health, vol. 39, no. 1, p. 48, 2021.

[11] A. G. Atanasov, B. Waltenberger, E.-M. Pferschy-Wenzig et al., "Discovery and resupply of pharmacologically active plant-derived natural products: a review," Biotechnology Advances, vol. 33, no. 8, pp. 1582-1614, 2015.

[12] A. M. Worku, "A review on significant of traditional medicinal plants for human use in case of Ethiopia," International Research Journal of Biotechnology, vol. 11, no. 2, pp. 1-2, 2020.

[13] D. Levene, D. I. Phillips, and S. Alemu, "Medical traditions and chronic disease in Ethiopia: a story of wax and gold?," Tropical Doctor, vol. 46, no. 3, pp. 122-125, 2016.

[14] M. W. Beyi, "Traditional medicinal plants in Ethiopia," International Journal of Biology, Physics \& Matematics, vol. 1, no. 1, pp. 80-87.

[15] Y. Yeshiwas, E. Tadele, and W. Tiruneh, "The dynamics of medicinal plants utilization practice nexus its health and economic role in Ethiopia: a review paper," International Journal of Biodiversity and Conservation, vol. 11, no. 1, pp. 31-47, 2019.

[16] A. Liberati, D. G. Altman, J. Tetzlaff et al., “The PRISMA statement for reporting systematic reviews and meta-analyses of studies that evaluate health care interventions: explanation and elaboration," PLoS Medicine, vol. 6, no. 7, article e1000100, 2009.

[17] Global plants on JSTOR [Internet][cited 2020 Sep 22]. Available from: https://plants.jstor.org/.

[18] A. Yirgu, K. Mohammed, and C. J. Geldenhuys, "Useful medicinal tree species of Ethiopia: comprehensive review," South African Journal of Botany, vol. 122, pp. 291-300, 2019.

[19] S. S. Semenya and M. J. Potgieter, "Ethnobotanical survey of medicinal plants used by Bapedi traditional healers to treat erectile dysfunction in the Limpopo province, South Africa," Journal of Medicinal Plant Research, vol. 7, no. 7, pp. 349-357.

[20] A. A. Ajao, N. P. Sibiya, and A. N. Moteetee, "Sexual prowess from nature: a systematic review of medicinal plants used as aphrodisiacs and sexual dysfunction in Sub-Saharan Africa," South African Journal of Botany, vol. 122, pp. 342359, 2019.

[21] J. A. O. Ojewole, S. E. Drewes, and F. Khan, "Vasodilatory and hypoglycaemic effects of two pyrano-isoflavone extractives from _Eriosema kraussianum_ N. E. Br. [Fabaceae] rootstock in experimental rat models," Phytochemistry, vol. 67, no. 6, pp. 610-617, 2006.
[22] H. Agisho, M. Osie, and T. Lambore, "Traditional medicinal plants utilization, management and threats in Hadiya Zone, Ethiopia," Journal of Medicinal Plants, vol. 2, no. 2, p. 15, 2014.

[23] S. Zerabruk and G. Yirga, "Traditional knowledge of medicinal plants in Gindeberet district, Western Ethiopia," South African Journal of Botany, vol. 78, pp. 165-169, 2012.

[24] T. Teklehaymanot, "An ethnobotanical survey of medicinal and edible plants of Yalo Woreda in Afar Regional State, Ethiopia," Journal of Ethnobiology and Ethnomedicine, vol. 13, no. 1, p. 40, 2017.

[25] T. Regassa, "Vascular plant diversity and ethnobotanical study of medicinal and wild edible plants in Jibat, Gedo and Chilimo Forests, West Shewa Zone of Oromia Region, Ethiopia [Internet] [Thesis]," Addis Ababa Universty; 2016 [cited 2020 Sep 21]. Available from: http://etd.aau.edu.et/handle/123456789/9371.

[26] F. Tewelde, M. Mesfin, and S. Tsewene, "Ethnobotanical survey of traditional medicinal practices in LaelayAdi-yabo District, Northern Ethiopia," Int J Ophthalmol Visual Sci, vol. 2, no. 4, p. 9, 2017.

[27] N. Amsalu, "An Ethno botanical study of medicinal plants in Farta Wereda,South Gonder Zone of Amhara Region Ethiopia [Internet] [Thesis]," Addis Ababa University; 2010 [cited 2020 Sep 21]. Available from: http://etd.aau.edu.et/handle/ $123456789 / 7282$.

[28] G. Chekole, Z. Asfaw, and E. Kelbessa, "Ethnobotanical study of medicinal plants in the environs of Tara-gedam and Amba remnant forests of Libo Kemkem District, Northwest Ethiopia," Journal of Ethnobiology and Ethnomedicine, vol. 11, no. 1, p. 4, 2015.

[29] A. Belayneh, S. Demissew, N. F. Bussa, and D. Bisrat, "Ethnomedicinal and bio-cultural importance of aloes from south and east of the Great Rift Valley floristic regions of Ethiopia," Heliyon, vol. 6, no. 6, article e04344, 2020.

[30] A. Teklay, B. Abera, and M. Giday, "An ethnobotanical study of medicinal plants used in Kilte Awulaelo District, Tigray Region of Ethiopia," Journal of Ethnobiology and Ethnomedicine, vol. 9, no. 1, p. 65, 2013.

[31] S. Araya, B. Abera, and M. Giday, "Study of plants traditionally used in public and animal health management in Seharti Samre District, Southern Tigray, Ethiopia," Ethiopia. J Ethnobiology Ethnomedicine., vol. 11, no. 1, p. 22, 2015.

[32] E. Tolasa, "Use and conservation of traditional medicinal plants by indigenous people in Gimbi Woreda, Western Wellega, Ethiopia [Internet] [Thesis]," Addis Ababa University; 2007 [cited 2020 Sep 21]. Available from: ee.

[33] N. Amsalu, Y. Bezie, M. Fentahun, A. Alemayehu, and G. Amsalu, Use and Conservation of Medicinal Plants by Indigenous People of Gozamin Wereda, An Ethnobotanical Approach, East Gojjam Zone of Amhara Region, Ethiopia, 2018, [cited 2020 Sep 21]; Available from: https://www .hindawi.com/journals/ecam/2018/2973513/.

[34] T. D. Temam, "Ethnobotanical study of medicinal plants of Mirab-Badwacho District, Ethiopia," Journal of BioScience and Biotechnology, vol. 5, no. 2, pp. 151-158, 2016.

[35] M. Kebebew, "Diversity, knowledge and use of medicinal plants in Abay Chomen District, Horo Guduru Wollega Zone, Oromia Region of Ethiopia," Journal of Medicinal Plant Research, vol. 11, no. 31, pp. 480-500, 2017.

[36] F. Mesfin, T. Seta, and A. Assefa, "An ethnobotanical study of medicinal plants in Amaro Woreda, Ethiopia," Ethnobotany Research and Applications, vol. 12, pp. 341-354, 2014. 
[37] M. Abebe and M. Chemdessa, "Ethnobotanical study of traditional medicinal plants of Gololcha District, Bale Zone of Oromia Region, Ethiopia [Internet],” 2013 [cited 2020 Sep 22]. Available from: /paper/Ethnobotanical-Study-of-TraditionalMedicinal-of-of-Abebe-

Chemdessa/3e47658ea716d29c46fa4ec56f20210428411aa5.

[38] R. Regassa, "Assessment of indigenous knowledge of medicinal plant practice and mode of service delivery in Hawassa city, southern Ethiopia," Journal of Medicinal Plant Research, vol. 7, no. 9, pp. 517-535, 2013.

[39] Z. Birhanu, "Traditional use of medicinal plants by the ethnic groups of Gondar Zuria District, North-Western Ethiopia," Journal of Natural Remedies, vol. 13, p. 9, 2013.

[40] B. Abera, "Medicinal plants used in traditional medicine by Oromo people, Ghimbi District, Southwest Ethiopia," Journal of Ethnobiology and Ethnomedicine, vol. 10, no. 1, p. 40, 2014.

[41] B. Sina and H. D. Degu, "Knowledge and use of wild edible plants in the Hula District of the Sidama Zone," Inter Jour of Bio-reso Stress Manag., vol. 6, no. 3, p. 352, 2015.

[42] H. Atnafu, T. Awas, S. Alemu, and S. Wube, "Ethnobotanical study of medicinal plants in selale mountain ridges, North Shoa, Ethiopia," International Journal of Biodiversity, vol. 2, 577 pages, 2018.

[43] M. Meragiaw, Z. Asfaw, and M. Argaw, "The status of ethnobotanical knowledge of medicinal plants and the impacts of resettlement in Delanta, Northwestern Wello, Northern Ethiopia [Internet]," 2016 [cited 2020 Sep 22]. Available from: https://www.hindawi.com/journals/ecam/2016/5060247/.

[44] D. Desissa and P. Binggeli, "Uses and conservation status of medicinal pants used by the Shinasha people in Ethiopia [Internet]," 2000 [cited 2020 Sep 22]. Available from: http:// www.mikepalmer.co.uk/woodyplantecology/ethiopia/ shinasha.html.

[45] F. Ayana, "Ethnobotanyoftraditional Medicinal plants in Hawa Gelan District,Kelem Wollega Zone of Oromia Region, Ethiopia [Internet] [Thesis]," Addis Ababa University; 2017 [cited 2020 Sep 22]. Available from: http://etd.aau.edu.et/ handle/123456789/4735.

[46] M. Gidey, T. Beyene, M. A. Signorini, P. Bruschi, and G. Yirga, "Traditional medicinal plants used by Kunama ethnic group in northern Ethiopia," Journal of Medicinal Plant Research, vol. 9, no. 15 , pp. 494-509, 2015.

[47] B. Etana, "Ethnobotanical study of traditional medicinal plants of Goma Wereda, Jima Zone of Oromia Region, Ethiopia [Internet] [Thesis]. Addis Ababa Universty," 2010 [cited 2020 Sep 22]. Available from: http://etd.aau.edu.et/handle/ $123456789 / 11339$.

[48] G. Chekole, "Ethnobotanical study of medicinal plants used against human ailments in Gubalafto District, Northern Ethiopia," Journal of Ethnobiology and Ethnomedicine, vol. 13, no. 1, p. 55, 2017.

[49] S. W. Yohannis, Z. Asfaw, and E. Kelbessa, "Ethnobotanical study of medicinal plants used by local people in Menz Gera Midir District, North Shewa Zone, Amhara Regional State, Ethiopia," Journal of Medicinal Plant Research, vol. 12, no. 21, pp. 296-314, 2018.

[50] N. Tuasha, B. Petros, and Z. Asfaw, "Medicinal plants used by traditional healers to treat malignancies and other human ailments in Dalle District, Sidama Zone, Ethiopia," Journal of Ethnobiology and Ethnomedicine, vol. 14, no. 1, p. 15, 2018.
[51] T. Teklehaymanot, "Ethnobotanical study of knowledge and medicinal plants use by the people in Dek Island in Ethiopia," Journal of Ethnopharmacology, vol. 124, no. 1, pp. 69-78, 2009.

[52] T. J. Aragaw, D. T. Afework, and K. A. Getahun, “Assessment of knowledge, attitude, and utilization of traditional medicine among the communities of Debre Tabor Town, Amhara Regional State, North Central Ethiopia: a cross-sectional study," Evidence-Based Complementary and Alternative Medicine [Internet], 2020, [cited 2020 Sep 22];2020:e6565131. Available from: https://www.hindawi.com/journals/ecam/ 2020/6565131/.

[53] M. Wubetu, T. Abula, and G. Dejenu, "Ethnopharmacologic survey of medicinal plants used to treat human diseases by traditional medical practitioners in Dega Damot district, Amhara, Northwestern Ethiopia," BMC Research Notes, vol. 10, no. 1, p. 157, 2017.

[54] A. Belayneh and N. F. Bussa, "Ethnomedicinal plants used to treat human ailments in the prehistoric place of Harla and Dengego valleys, eastern Ethiopia," Journal of Ethnobiology and EthnomedicineFull Text [Internet]. 2014 [cited 2020 Sep 22]. Available from: https://ethnobiomed.biomedcentral.com/articles/10.1186/1746-4269-10-18.

[55] A. Kefalew, Z. Asfaw, and E. Kelbessa, "Ethnobotany of medicinal plants in Ada'a District, East Shewa Zone of Oromia Regional State, Ethiopia," Journal of Ethnobiology and Ethnomedicine, vol. 11, no. 1, p. 25, 2015.

[56] G. Gebeyehu, Z. Asfaw, A. Enyew, and N. Raja, “(16) (PDF) An ethnobotanical study of traditional use of medicinal plants and their conservation status in Mecha Wereda, West Gojjam Zone of Amhara Region, Ethiopia [Internet]," 2014, [cited 2020 Sep 22]. Available from: https://www.researchgate.net/ publication/337672633_AN_ETHNOBOTANICAL_ STUDY_OF_TRADITIONAL_USE_OF_MEDICINAL_ PLANTS_AND_THEIR_CONSERVATION_STATUS_IN_ MECHA_WEREDA_WEST_GOJJAM_ZONE_OF_ AMHARA_REGION_ETHIOPIA.

[57] N. Abdurhman, "Ethnobotanical study of medicinal plants used by local people in Ofla Wereda, Southern Zone of Tigray Region, Ethiopia [Internet] [Thesis]," Addis Ababa University; 2010 [cited 2020 Sep 22]. Available from: http://etd.aau .edu.et/handle/123456789/1869.

[58] T. Teklehaymanot and M. Giday, "Ethnobotanical study of medicinal plants used by people in Zegie Peninsula, Northwestern Ethiopia," Journal of Ethnobiology and Ethnomedicine, vol. 3, no. 1, p. 12, 2007.

[59] A. Enyew, Z. Asfaw, E. Kelbessa, and R. Nagappan, “Airiti library_ethnobotanical+study+of+traditional+medicinal+plants+in+and+around+Fiche+District,+Central+Ethiopia," 2014 [cited 2020 Sep 22]; Available from: https://www .airitilibrary.com/Publication/alDetailedMesh?docid= 20410778-201407-201507280023-201507280023-154-167.

[60] S. Ayalew, A. Kebede, A. Mesfin, and G. Mulualem, "Ethnobotanical study of medicinal plants used by agro pastoralist Somali people for the management of human ailments in Jeldesa cluster, Dire Dawa Administration, Eastern Ethiopia," Journal of Medicinal Plant Research, vol. 11, no. 9, pp. 171$187,2017$.

[61] M. Giday, T. Teklehaymanot, A. Animut, and Y. Mekonnen, "Medicinal plants of the Shinasha, Agew-awi and Amhara peoples in Northwest Ethiopia," Journal of Ethnopharmacology, vol. 110, no. 3, pp. 516-525, 2007. 
[62] D. Beche, G. Gebeyehu, and K. Feyisa, "Indigenous utilization and management of useful plants in and around Awash National Park, Ethiopia," Journal of Plant Biology \& Soil Health, vol. 3, no. 1, p. 12, 2016.

[63] M. W. Beyi, “(16) (PDF) Ethnobotanical study of traditional medicinal plants in Adami Tulu Jido Kombolcha District, Oromia, Ethiopia [Internet]," ResearchGate. 2018 [cited 2020 Sep 22]. Available from: https://www.researchgate.net/ publication/331981089_ETHNOBOTANICAL_STUDY_OF_ TRADITIONAL_MEDICINAL_PLANTS_IN_ADAMI_ TULU_JIDO_KOMBOLCHA_DISTRICT_OROMIA_ ETHIOPIA.

[64] M. Gebrehiwot, "An ethnobotanical study of medicinal plants in Seru Wereda, Arsi Zone of Oromia Region, Ethiopia [Internet] [Thesis]," Addis Ababa University; 2010 [cited 2020 Sep 22]. Available from: http://etd.aau.edu.et/handle/123456789/ 6699.

[65] F. Mesfin, S. Demissew, and T. Teklehaymanot, "An ethnobotanical study of medicinal plants in Wonago Woreda, SNNPR, Ethiopia | SpringerLink [Internet]," 2009 [cited 2009 Sep 22]. Available from: https://link.springer.com/article/10.1186/ 1746-4269-5-28.

[66] A. A. Lemma, "Ethnobotanical study of traditional medicinal plants in Debark District, North Gondar, Ethiopia [Internet] [Thesis]," 2017 [cited 2020 Sep 22]. Available from: http://10 .139.8.247:80/jspui/handle/123456789/901.

[67] B. M. Wolditsadik, "Ethnobotanical investigation of traditional medicinal plants in Dugda District, Oromia Regio," SM J Med Plant Stud., vol. 2, no. 1, pp. 1-19, 2018.

[68] G. Bekele and P. R. Reddy, "Ethnobotanical study of medicinal plants used to treat human ailments by Guji Oromo tribes in Abaya District, Borana, Oromia, Ethiopia," Universal Journal of Plant Science, vol. 3, no. 1, p. 4, 2015.

[69] T. Seifu, K. Asres, and T. Gebre-Mariam, “(16) (PDF) Ethnobotanical and ethnopharmaceutical studies on medicinal plants of Chifra District, Afar Region, North Eastern Ethiopia [Internet]," ResearchGate. 2006 [cited 2020 Sep 22]. Available from: https://www.researchgate.net/publication/259752372_ Ethnobotanical_and_Ethnopharmaceutical_Studies_on_ Medicinal_plants_of_Chifra_District_Afar_Region_North_ Eastern_Ethiopia.

[70] Y. S. Birhan, S. Leshe Kitaw, Y. Abebe Alemayehu, and M. N. Minuye, "Ethnobotanical study of medicinal plants used to treat human diseases in Enarj Enawga District, East Gojjam Zone, Amhara Region, Ethiopia," SM J Med Plant Stud., vol. 1, no. 1, pp. 1-20, 2017.

[71] B. Tsegay, E. Mazengia, and T. Beyene, "Short Communication: diversity of medicinal plants used to treat human ailments in rural Bahir Dar, Ethiopia," Asian Journal of Forestry [Internet], 2019, [cited 2020 Sep 22];3(2). Available from: https://smujo.id/ajf/article/view/4163.

[72] N. Mekonnen and E. Abebe, "Ethnobotanical knowledge and practices of traditional healers in Harar, Haramaya, Bati and Garamuleta, Eastern Ethiopia," Ethiopian Veterinary Journal, vol. 21, no. 2, pp. 40-61, 2017.

[73] T. Tesfaye, "Use and Management of Medicinal Plants by People of Melka Belo Woreda," Haramaya University, East Hararghe, Oromia Region, Ethiopia, 2016.

[74] G. G. Mengesha, "Ethnobotanical survey of medicinal plants used in treating human and livestock health problems in Mandura Woreda of Benishangul Gumuz, Ethiopia," Adv Med Plant, vol. 4, no. 1, p. 17.
[75] A. J. Afolayan and M. T. Yakubu, "Erectile dysfunction management options in Nigeria," The Journal of Sexual Medicine., vol. 6, no. 4, pp. 1090-1102, 2009.

[76] P.-M.-A. H. Mfengwana and S. S. Mashele, "Medicinal properties of selected asparagus species: a review," IntechOpen [Internet], 2019, [cited 2020 Sep 22]. Available from: https://www .intechopen.com/books/phytochemicals-in-human-health/ medicinal-properties-of-selected-asparagus-species-a-review.

[77] S. A. Pratap and S. Rajender, "Potent natural aphrodisiacs for the management of erectile dysfunction and male sexual debilities," Frontiers in Bioscience (Scholar Edition), vol. 4, pp. 167$180,2012$.

[78] Evaluation of the spermatogenetic effect of the root, Google Scholar [Internet][cited 2021 May 6]. Available from: https://scholar.google.com/scholar?hl=en\&as_sdt= $0 \% 2$ C5\&as_ylo=2017\&q=Evaluation + of + the+spermatogenetic+effect+of +the+root +of +Ricinus +communis+Linn.+in+male + Wistar+rats. \&btnG $=79$.

[79] A. S. Tajuddin, A. Latif, and I. A. Qasmi, "Effect of 50\% ethanolic extract of Syzygium aromaticum (L.) Merr. \& Perry. (clove) on sexual behaviour of normal male rats," BMC Complementary and Alternative Medicine, vol. 4, no. 1, p. 17, 2004.

[80] A. S. Tajuddin, A. Latif, and I. A. Qasmi, "Aphrodisiac activity of $50 \%$ ethanolic extracts of Myristica fragrans Houtt. (nutmeg) and Syzygium aromaticum (L) Merr. \& Perry. (clove) in male mice: a comparative study," BMC Complementary and Alternative Medicine, vol. 3, no. 1, p. 6, 2003.

[81] R. K. Mishra and S. K. Singh, "Safety assessment of_Syzygium aromaticum_flower bud (clove) extract with respect to testicular function in mice," Food and Chemical Toxicology, vol. 46, no. 10, pp. 3333-3338, 2008.

[82] P. Kamtchouing, Y. Mbongue, D. Théophile, and H. B. Jasta, "(16) Evaluation of androgenic activity of Zingiber officinale and Pentadiplandrabrazzeana in male rats | Request PDF," 2003 [cited 2020 Sep 23]; Available from: https://www .researchgate.net/publication/10968369_Evaluation_of_ androgenic_activity_of_Zingiber_officinale_and_ Pentadiplandrabrazzeana_in_male_rats.

[83] S. R. Pare, V. S. Zade, and V. G. Thakare, "Evaluation of the potential aphrodisiac activity of aqueous, chloroform and alcohol extract of Gloriosa superba in male albino rat," International Journal of Theoretical \& Applied Sciences, vol. 8, no. 2, p. 39.

[84] F. B. Abebe, M. M. Asfaw, and T. T. Tolossa, "Medicinal plant species used to treat tonsillitis in Ethiopia: a systematic review," JPS., vol. 9, no. 1, p. 34, 2020.

[85] E. N. Ipona, C. L. Inkoto, G. N. Bongo et al., "Ethno-Botanical Survey and Ecological Study of Medicinal Plants Traditionally Used Against Erectile Dysfunction in Democratic Republic of the Congo," Bioscience and Bioengineering, vol. 4, no. 4, p. 8, 2018.

[86] M. Kamatenesi-Mugisha and H. Oryem-Origa, "Traditional herbal remedies used in the management of sexual impotence and erectile dysfunction in Western Uganda," African Health Sciences, vol. 5, no. 1, pp. 40-49, 2005. 